\title{
Giant thoracic meningocele associated with neurofibromatosis 1
}

Figure Giant thoracic meningocele

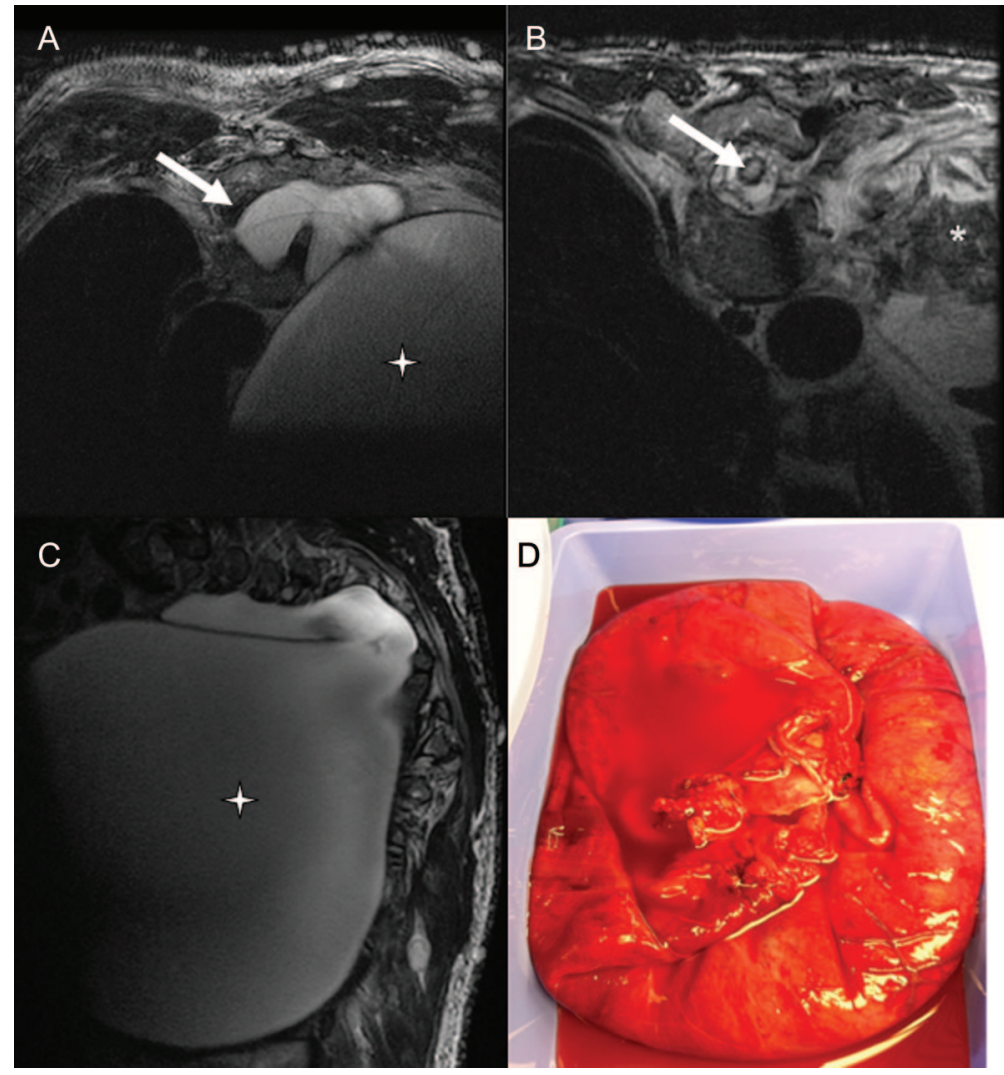

(A, C) Axial and sagittal T2-weighted MRI demonstrating a giant meningocele (star) at the left T8 vertebral level. (B) Postoperative MRI demonstrating complete resection of the meningocele with reexpansion of the spinal cord (arrows) and lung (asterisk). (D) Gross specimen of the resected meningocele.

A 48-year-old man with neurofibromatosis 1 presented with progressive shortness of breath over the course of 4 years. There was prominent kyphoscoliosis. Imaging revealed a large thoracic meningocele compressing the left lung (figure). He then developed progressive lower extremity weakness and a decline in pulmonary function. $\mathrm{He}$ underwent drainage, resection, and closure of his thoracic meningocele. In a second stage, he underwent spinal cord decompression and fusion. He is no longer requiring supplemental oxygen and is gaining strength. Thoracic meningoceles may occur in neurofibromatosis secondary to congenital mesodermal dysplasia and hypoplastic bone changes. ${ }^{1,2}$

Brian P. Walcott, MD, Kristopher T. Kable, MD, PhD, John C. Wain, MD, Lawrence F. Borges, MD, Boston, MA Disclosure: The authors report no disclosures.

Address correspondence and reprint requests to Dr. Lawrence F. Borges, Neurosurgical Spine Service, Neurosurgical Stereoscopic 3-dimensional Video Laboratory, Massachusetts General Hospital, White 1205, 55 Fruit Street, Boston, MA 02114; LBorges@partners.org

1. Miles J, Pennybacker J, Sheldon P. Intrathoracic meningocele: its development and association with neurofibromatosis. J Neurol Neurosurg Psychiatry 1969;32:99-110.

2. Rainov NG, Heidecke V, Burkert W. Thoracic and lumbar meningocele in neurofibromatosis type 1: report of two cases and review of the literature. Neurosurg Rev 1995;18:127-134. 


\section{Neurology}

\section{Giant thoracic meningocele associated with neurofibromatosis 1 \\ Brian P. Walcott, Kristopher T. Kahle, John C. Wain, et al. \\ Neurology 2011;76;1943 \\ DOI 10.1212/WNL.0b013e31821d7667}

\section{This information is current as of May 30, 2011}

\section{Updated Information \& Services}

\section{References}

Subspecialty Collections

Permissions \& Licensing

Reprints including high resolution figures, can be found at: http://n.neurology.org/content/76/22/1943.full

This article cites 2 articles, 1 of which you can access for free at: http://n.neurology.org/content/76/22/1943.full\#ref-list-1

This article, along with others on similar topics, appears in the following collection(s):

All Spinal Cord

http://n.neurology.org/cgi/collection/all_spinal_cord Neurofibromatosis

$\mathrm{http} / / / \mathrm{n}$.neurology.org/cgi/collection/neurofibromatosis

Information about reproducing this article in parts (figures,tables) or in its entirety can be found online at:

http://www.neurology.org/about/about_the_journal\#permissions

Information about ordering reprints can be found online:

http://n.neurology.org/subscribers/advertise

Neurology ${ }^{\circledR}$ is the official journal of the American Academy of Neurology. Published continuously since 1951, it is now a weekly with 48 issues per year. Copyright Copyright (? 2011 by AAN Enterprises, Inc.. All rights reserved. Print ISSN: 0028-3878. Online ISSN: 1526-632X.

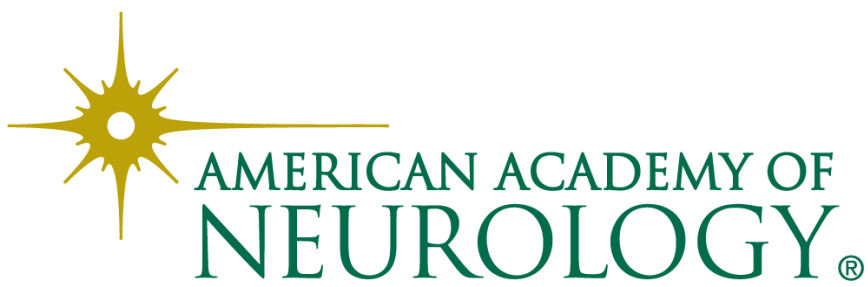

